\begin{tabular}{|l|l|l||}
\hline \multicolumn{2}{|c|}{ PublisherInfo } \\
\hline \hline PublisherName & $:$ & BioMed Central \\
\hline \hline PublisherLocation & $:$ & London \\
\hline \hline PublisherImprintName & $:$ & BioMed Central \\
\hline \hline
\end{tabular}

\title{
American College of Rheumatology
}

\begin{tabular}{||l|l|l||}
\hline \multicolumn{2}{|c||}{ ArticleInfo } \\
\hline \hline ArticleID & $:$ & 4 \\
\hline \hline ArticleDOI & $:$ & $10.1186 /$ ar-1999-1-webreport0006 \\
\hline \hline ArticleCitationID & $:$ & 0006 \\
\hline \hline ArticleSequenceNumber & $:$ & 4 \\
\hline \hline ArticleCategory & $:$ & Web Report \\
\hline \hline ArticleFirstPage & $:$ & 1 \\
\hline \hline ArticleLastPage & $:$ & 3 \\
\hline \hline & $:$ & RegistrationDate : 1999-10-26 \\
ArticleHistory & $:$ & OnlineDate $\quad$ 1999-10-26 \\
\hline \hline ArticleCopyright & $:$ & Current Science Ltd1999 \\
\hline \hline ArticleGrants & $:$ & \\
\hline \hline ArticleContext & $:$ & 1307511 \\
\hline \hline
\end{tabular}




\section{Content}

This is the official website of the ACR and the Association of Rheumatology Health Professionals(ARHP). There is a members only section, but most information on the site is available without registration or membership of the ACR.

The site hosts the two official journals of the ACR/ARHP, Arthritis \& Rheumatism (A\&R) and Arthritis Care \& Research, and the ACR newsletter/ARHP News (full-text available free). Tables of contents and browsable author/subject indices going back to 1995 are available for both peer-reviewed journals (and short abstracts are available for $A \& R$ ), but neither journal has links to full-text articles online or to PubMed abstracts.

The geographical and alphabetical directory of ACRmembers ('Find a rheumatologist') is a very usefulresource. Lots of information about the ACR (eg staffdirectory) and its activities (eg upcoming conferences), as well as subscription details on how to join the ACR, is available online. Searchable ACR conference abstracts are available for the 63rd Annual Scientific Meeting (1998), and for the 64th Annual Scientific Meeting in November 1999 (well before the conference is due to start); these are free, the only requirement is registration. You can also register online for conferences. More information about ACR events can be found in the 'Virtual Press Room'. There are also news items on arthritis drugs in the section called 'Hotlines', a set of 'Position papers' selected from $A \& R$, a press release archive (going back to 1996) and a slide presentation on patient care, costs and outcomes. The website includes information about the 'Research and Education Foundation', and the 'Advocates for Arthritis Program', as well as useful practical features, such as 'how to obtain a hotel room in Boston'.

\section{Content}

This site is well organised and easy to navigate, with a well laid-out site map and full searchability. It also contains a useful list of relevant external links to related websites and conferences.

\section{Timeliness}


This site is updated frequently, as indicated by the copyright dates at the bottom of each page. Download time is quick, especially for the information sections on Treatment guidelines and Classification criteria.

\section{Reviewer's evaluation}

A substantial amount of the information contained in the site has been sourced from $A \& R$, such as a downloadable pdf of the 'unified list of acronymsfor the rheumatology literature', and other general reference features. This site is user-friendly and provides detailed information for both patients and physicians. It is a superb resource for all those involved in rheumatology, and is especially helpful for those planning to attend ACR and ARHP events. 